\title{
Grounds for Criminalistic Classification of Crimes against Human Life and Health Committed by Convicts Serving Imprisonment Sentences in Places of Deprivation of Liberty
}

\author{
NIKOLAI G. SHURUKHNOV \\ Research Institute of the Federal Penitentiary Service of Russia, Moscow, Russian \\ Federation \\ ORCID: https://orcid.org/0000-0003-1132-760X, e-mail: matros49@mail.ru
}

\section{OLEG M. DECHKIN}

Vologda Institute of Law and Economics of the Federal Penitentiary Service of Russia, Vologda, Russian Federation

ORCID: https://orcid.org/0000-0002-4956-8655, e-mail: olegd4105@mail.ru

\begin{abstract}
Introduction: the article considers grounds for criminalistic classification of crimes causing intentional injuries committed by convicts serving sentences in places of deprivation of liberty. Purpose: based on the analysis and generalization of theoretical and practical materials, an attempt is made to formulate the most characteristic grounds for the criminalistic classification of the analyzed criminal acts and reveal their contents. Methods: the dialectical method of cognition, general scientific methods of analysis and generalization, empirical methods of description, interpretation; theoretical methods of formal and dialectical logic are used in the research. Results: the article reveals in detail the content of general (territory, situation, community of correctional institutions; prevalence of informal norms of behavior in places of deprivation of liberty, which most convicts adhere to) and private grounds (specifics of personality traits of a criminal, victim and witnesses; specifics of behavior before and after crime commission) for classification of crimes that make up the group for which the investigation method will be worked out. Conclusions: based on the available research, which highlights the universal basis - the criminal legal object, it is concluded that there are two groups of grounds (general and special) for classification of crimes causing intentional harm to life and health committed by convicts serving imprisonment sentences.

Ke y w o r d s: places of deprivation of liberty; convicted persons; crimes; intentional injuries; classification; grounds; investigation; methodology.

12.00.12 - Criminalistics; forensic examination activities; law enforcement intelligencegathering activities

For citation: Shurukhnov N.G., Dechkin O.M. Grounds for criminalistic classification of crimes against human life and health committed by convicts serving imprisonment sentences in places of deprivation of liberty. Penitentiary Science, 2021, vol. 15, no. 4 (56), pp. 886-895. DOI 10.46741/2686-9764-2021-15-4-886-895.
\end{abstract}

\section{Introduction}

In 2020, 1,181 crimes were committed by arrested and convicted persons in institutions of the penal enforcement system of the Russian Federation (hereinafter referred to as PES) [15]. Approximately $5 \%$ is crimes related to intentional injuries. These are 8 cases of murder (Article 105 of the Criminal Code of the Russian Federation), 4 cases of attempted murder (Ar- ticles 30 and 105 of the CC RF), 24 cases of intentional infliction of a grave injury (Article 111 of the CC RF), and 24 cases of intentional infliction of injury of average gravity (Article 112 of the CC RF) [15].

Unfortunately, there are no statistics data provided by the Research Institute of Information Technologies of the Federal Penitentiary Service of Russia for crimes stipulated by Arti- 
cle 115 of the Criminal Code of the Russian Federation. Though, in our opinion, they pose an increased public danger, since they encroach on fundamental human values - people's life and health. The criterion of intentional infliction of injury of light gravity in the official accounting is absent not only due to the appropriate management attitude, but also the lack of proper practice of countering this illegal activity. This negatively affects not only moral and psychological climate of inmates, but also contributes to commission of other more dangerous crimes. According to our estimates, about $7 \%$ of such crimes was committed in 2020 . This means that in absolute terms their number was significantly greater than the number of the crimes provided for in Articles 105, 111, 112 of the CC RF combined.

Hence, we attribute crimes provided for in Article 115 of the CC RF to the subject of our study - a group of crimes causing intentional harm to life and health committed by convicts serving sentences in places of deprivation of liberty. Our goal is to establish grounds for developing a unified methodology for investigation of such crimes. This means identifying specific, informative grounds that have essential features inherent in each illegal act and determine the specifics of commission and investigation of crimes under consideration.

\section{Research}

Our research is aimed at identifying conditions of committing certain crimes against human life and health with regard to the specifics of personality traits of perpetrators and victims and their behavior during investigation of the crime committed by convicts serving sentences in penal institutions. It is this approach that makes it possible to develop a purposeful, practically significant investigation methodology that will differ from a similar one, designed for other conditions of illegal activity and a different category of subjects and victims.

For correct classification of such crimes, it is necessary to accurately determine the basis of their division, that is, the indicia (rather the totality) by which they are compared with each other. It is worth mentioning that sometimes, in order to develop an investigation methodology, an attempt is made to adjust crimes to a certain general pattern, without taking into account their uniqueness. Opponents, on the contrary, reject the very idea of finding a certain unity and similarity between a group of crimes, insisting on their individual specifics. As often happens in scientific research, the truth is somewhere in between. We believe that the most adequate approach to classification and, accordingly, types of crimes is the one that takes into account their general features in terms of the level of abstraction, the depth of the designation of illegal activity, their informativeness, accuracy of definitions, structure and qualification possibilities.

Once again, we point out that classification is always carried out on the basis of certain grounds that serve as one or another characteristic feature of the corresponding group of crimes. It is intended to be a starting point for development of various types of methods [18; 19; 24], ensuring their purposefulness and investigation effectiveness. Besides, classification is of some economic value, since it is possible to develop recommendations for a range of crimes. Classification helps accumulate necessary information, organize processes of cognition (study of practice), as well as widen knowledge about the crime committed and thereby determine the method that could optimize the upcoming investigation [16, p. 202].

For a long time, to determine a group of crimes, domestic criminologists relied on criminal legislation norms, where the object of criminal encroachment was of particular importance. The work of I.N. Yakimov "Criminalistics. The manual of criminal technique and tactics", published in 1925, singles out murder, theft, fraud, forgery (objects of crimes). When disclosing the content of the "methodology" (as Part 3 of the edition was called by I.N. Yakimov), other classification grounds were also used, in particular, a method of committing a crime (murder by strangulation [25, pp. 370-371], poisoning [25, pp. 371-374]), as well as direct connection of the subject and object (infanticide [25, pp. 375-376]).

It should be noted that the first Soviet textbooks on criminology presented investigation methods, describing an object of the crime, a method of its commission, concealment techniques, characteristics of the criminal's personality, his/her attitude to the direct subject of encroachment [12].

Without dwelling on evolution of the bases of criminalistic classification of crimes, as it is described in detail in the works of R.S. Belkin [4, pp. 193-201]; R.S. Belkin and A.I. Vinberg [3, pp. 65-69]; A.R. Belkin [2]; A.Y. 6]; V.A. Ob- 
raztsov [14], we will touch only on those aspects that meet goals of the present research. The indicated trend, i.e. the use of criminal law provisions of the crime object as a classification basis to design the investigation method, is still relevant. There is no doubt about its validity, since its perfection proven by practice does not lend itself to criticism, since it allows solving the strategic task of criminology, including elaboration and systematization of private forensic methods of investigation of certain types of crimes. A.N. Kolesnichenko was among the first to point out its secondary role. However, at the same time, he spoke about their general meaning [11, p. 14]. Indeed, the criminal law classification cannot fully satisfy all needs of the forensic theory and investigative practice, in particular, we cannot limit ourselves only to those indicia and characteristics of crimes that the science of criminal law studies [5, p. 155; 16, p. 203]. In fact, it does not reveal crime investigation effectiveness, and is intended to focus on correct qualification of the illegal act [10]. Therefore, with regard to the realities of today's life, it is necessary to collect empirical data, analyze them thoroughly in order to identify patterns to be used for classifying, including in relation to the subject of our study.

The stated above is connected with the fact that modern human life, on a global scale, has undergone significant changes, including in correctional facilities. Nowadays the driving force is the new economic and legal order, the legal status of citizens, the systemically changed production and economic mechanism and organizational and managerial process, as well as scientific and technological progress and informatization of all spheres of life, without exception. All this is mirrored in activities of penitentiary institutions.

Speaking about some of the "locomotives" of modern life, we should emphasize that information technology has made changes in the ways of committing crimes. Some of them have become contactless, remote, with overcoming significant distances, covering significant areas. Cell phones have created prerequisites for convicts in correctional facilities to commit fraud, with the search for victims who are at a considerable distance from the place of imprisonment. Unmanned aerial vehicles make it possible to establish the presence and location of material assets and plantations of narcotic plants, deliver narcotic drugs and psychotropic substances to convicts. The COVID-19 coronavirus pandemic has affected the nature of criminal activity, giving rise to new types of crimes: forgery and illegal trafficking of vaccines, medicines, vaccination certificates, PCR tests. All of the above has affected the frequency of interpersonal conflicts of convicts, since the pandemic has strengthened the already strict regime of serving sentences.

It should be highlighted that changes in everyday life and criminal activity have resulted in correction in the use of means and methods of detecting crimes, the process of their investigation and establishment of certain circumstances of illegal activity. Consequently, there appears another direction of empirical data collection, their thorough analysis, identification of patterns to establish new (additional) grounds for criminalistic classification of crimes in order to develop recommendations for investigation.

The proposals formulated by R.S. Belkin played a significant role in the development of the theory of criminalistic classification of crimes. In his opinion, the corpus delicti should be widened and its content should be taken as the starting directions for studying the depth of disclosure of specific features and patterns of the studied phenomena. Crimes can be classified by:

- a subject of the crime (committed individually and by a group; for the first time and repeatedly; by persons who are in a special relationship with the direct object of the assault and are not in such a relationship; adults and minors; men and women);

- a object of the crime (by personality of a victim; nature of the direct subject matter of the encroachment; place of crime commission; by methods and means of protecting the subject matter of the encroachment);

- a objective side of the corpus delicti (according to the method of committing the crime; according to the method of concealing the crime, if it is not included as an integral part of the method of committing the crime);

- a subjective side of the crime (committed with premeditated intent and sudden intent)" [4, p. 198].

Ten years later V.A. Obraztsov pointed out some shortcomings in the above approach, in particular, unclear systematization of the grounds for criminalistic classification of crimes; lack of an exhaustive list of the grounds for classification and indicators of other crimerelated systems [14, p. 15-16]. In his opinion, to 
distinguish crimes, criminalists can also use the following grounds: a) content of the crime: indicia of a criminal, object, means of encroachment, process, results, motive and purpose of illegal activity; b) crime situation; c) activities to identify and solve crimes [14, pp. 80-127].

V.A. Obraztsov's proposals, in turn, were also criticized [7, p. 141; 8, p. 57; 13, pp. 72-73], in particular, in terms of attribution of features of crime detection and solution activities to the classification of crimes [2, p. 23; 7, p. 141]. However, attention should be paid to at least two circumstances: the classification is aimed at building a method for investigating an illegal act; V.A. Obraztsov, revealing shortcomings of Belkin's classification, indicates a lack of consideration of characteristics of other systems [14, p. 14-15], which include not only features of the process of detecting and solving crimes, but also causes and conditions that contributed to their commission, as well as correlations and determinants of criminal activity.

If we turn to the methodology, we can conclude that it explores scientific knowledge analysis methods, their structure, the place and role of different forms of cognition and methods of constructing various systems of scientific knowledg" [17, p. 5-6]. It seems that the process of investigation is important in terms of the subject of cognition, as V.A. Obraztsov claims. Analyzing the sources devoted to the issues of criminalistic classification, namely the works of R.S. Belkin, A.N. Vasil'ev, I.A. Vozgrin, V.K. Gavlo, Yu.P. Garmaev, A.Yu. Golovin, I.F. Gerasimov, V.A. Zhbankova, V. Zhelenskii, A.N. Kolesnichenko, V.E. Kornoukhov, V.P. Lavrov, A.F. Lubin, G.M. Meretukov, N.E. Meretskii, V.A. Obraztsov, A.A. Protasevich, V.G. Tanasevich, A.V. Shmonin, N.G. Shurukhnov, N.P. Yablokov, A.A. Eksarkhopulo, we come to conclusion that the data of other sciences, including criminal procedure, criminology, computer science, customs, psychology, as well as a set of various circumstances characterizing a crime, offender, and victims, can be considered as grounds for it.

I.F. Gerasimov considers methods of committing crimes, the degree of their concealment and deception, illegal experience of the subject, the place of crime commission as the basis of classification [5, p. 155]. So, the baseline in his classification is simultaneously components of the forensic characteristics. The task of a modern scientist who forms the methodology of in- vestigation is to determine what is common to a certain group of crimes, manifests itself as a pattern revealed as a result of empirical research.

The great Russian criminologist R.S. Belkin formulated the baseline of the criminalistic classification of crimes more than 45 years ago. His detailed scheme is still relevant today and is taken as a basis by modern researchers. We also use it as a starting point in attempt to form a criminalistic basis for crime classification. On its basis targeted methodological recommendations for the investigation will be formed.

In our opinion, the grounds for criminalistic classification of crimes stipulated by Articles 105, 111, 112 and 115 of the Criminal Code of the Russian Federation committed by convicts in places of deprivation of liberty can be differentiated into two groups of interrelated and mutually conditioned factors that influence the process of their commission and investigation: general (common to all) and private (related to the part of crimes under consideration committed in correctional facilities).

General ones include: a) a territory, situation, CF environment; b) prevalence of informal norms of behavior in places of deprivation of liberty, which most convicts adhere to.

Private are: a) specifics of personality traits of the subject of the crime, witnesses; b) characteristics of personality traits of the victim, specifics of behavior before and after commission of the crime causing intentional harm to life and health.

Territory, situation, CF environment. It is the territory, where crimes are committed and subjects of the crime, witnesses and victims stay 24 hours a day (before and after crime commission). It is strictly limited, constantly guarded and controlled by technical means. The territory of a correctional colony, as a rule, includes two independent parts: residential and industrial (production). The residential area is divided into several local areas. They create various conditions for serving sentences within the same correctional colony: normal, light, strict. Convicts live in dormitories (with appropriate communal facilities). In front of them there is a fenced-off area intended for walks.

The residential area consists of a complex of buildings and structures designed to accommodate a food hall, bath and laundry complex, boiler room, medical unit, pharmacy (hospital in some correctional colonies), school, club with a 
library, vocational college, and store. In the production area there are workshops, plots, workshops, warehouses and utility rooms, which differ in terms of production activity, manufactured products.

Engineering and technical means of protection and supervision are located in residential and industrial areas, along the territory, at checkpoints in accordance with the requirements of the Order of the Ministry of Justice of the Russian Federation No. 279 dated September 4, 2006 "On approval of the Instruction on the equipment of engineering and technical means of protection and supervision of objects of the penal enforcement system" (as amended June 17, 2013). They are designed to prevent and suppress commission of crimes and convicts' violations of the established detention regime, as well as obtain necessary information about their behavior. For these purposes, regime measures (inspections, searches) are implemented, audio-visual, electronic and other technical means of supervision and control are used (Articles 82, 83 of the CC RF).

According to the Law of the Russian Federation No. 5473-1 of July 21, 1993 (as amended May 26, 2021) "On institutions and bodies executing criminal penalties in the form of deprivation of liberty" and the Order of the Ministry of Justice of the Russian Federation No. 178 of March 9, 2007 "On approval of the Regulations on regime requirements in the territory adjacent to the institution subordinate to the territorial body of the penal enforcement system", the territory of correctional facilities also includes adjacent areas where regime requirements are established. Within their limits, the institution administration can implement a set of regime measures provided for by laws and regulatory legal acts.

The specific situation of correctional colonies is caused by a high concentration of convicts on a limited territory. Any actions of convicts in such a community are under mutual supervision, as well as under visual or electronic and secret control carried out by the correctional facility administration.

The community is interconnected, mutually conditioned by the situation and present everywhere, creating various (including criminal) situations. Its breath is felt everywhere, it knows everything, controls everyone serving a sentence of imprisonment. It is an investigator, court, prosecutor, lever that enforces decisions made by leaders of the thieves' world. It is difficult to get away from it, it has sticky fingers and great opportunities. The community forms and implements unofficial norms of behavior (prison ideology) and monitors their strict implementation.

Behavior of convicts as representatives of the community surrounding conflict participants, both before crime commission and during investigation, is specific. If defined in one word, it is demonstration of complete indifference to the fate of the subject of the illegal act and the victim. It is demonstration of external behavior; the internal is individual and closed, individual experiences are not showed, the actual attitude to the incident is dissimulated. To a certain extent, this behavior is justified: on the one hand, convicts follow the requirements (particularly heightened in places of deprivation of liberty) of taboo on the invasion of privacy and, on the other, try not to score an own goal, as it might change the prevailing way of life, which is tolerable and common in specific conditions of the correctional facility.

Illegal acts in criminal justice institutions are committed most often in the presence of community representatives. It should be borne in mind that they monitor the situation and become interested in conflicts and illegal actions that disrupt their monotonous life. Knowing this, convicts do not cooperate with the subject of the investigation and refuse to testify. The motives for this approach are different: a) a lack of desire (fear) to violate the "ban established" by unofficial norms of behavior; b) solidarity, sincere sympathy for the subject of the crime, since the victim has been "asking for" it c) fear of deviating from the position taken by the criminal and thus doing harm to him; d) attitude not to interfere in other people's affairs directly or indirectly, etc.

Refusal to testify makes it possible to avoid a subsequent (possible) summons to court, otherwise it will create additional discomfort for the convicted person associated with moving to court in a special transport, staying in court surrounded by a convoy.

When investigating crimes committed by convicts serving sentences in penitentiary institutions, the community, by virtue of existing traditions, opposes this process actively or passively. Subjects of the investigation should not hope to receive testimony from eyewitness- 
es in the situation where even several people observed it. It should not be surprising when, instead of a really truthful answer to the investigator's question about circumstances of intentional harm to life or health, a convicted eyewitness, staying in an extremely limited space (in the cell of the penal isolation unit) where the crime was committed and necessarily observing illegal actions, will give such answers: "I have not seen anything"; "I was reading a prayer at that time"; "I was busy with myself"; "I was in a state of personal reflection and did not pay attention to this fuss". We will not discuss the answers, we focused our attention on during the study, but emphasize that they are similar to those given by a person who assisted in the crime commission. It is found out that convicts can actively give incriminating testimony in cases when interests of the opposing informal groups of convicts (groups of negative orientation) collide.

Prevalence of unofficial norms of behavior, which the majority of convicts adhere to. The situation, where, figuratively speaking, every log of a wooden frame, every brick in the masonry of the building is impregnated with special norms of life, affects reconstruction of convicts' inner world to varying degrees. They become cautious, introverted, circumspect, uninitiative, and spiteful with elements of aggression. To a certain extent, this is characteristic of any community of people concentrated in specific conditions of a relatively closed nature. Each such community is formed, functions and is preserved as an independent under the influence of internal factors. One of them is traditions, and in relation to the community of convicts - unofficial norms of behavior, the observance of which is stricter, and the punishment for deviation from them is inevitable and cruel.

In conditions of places of deprivation of liberty, there are two groups of norms that define (regulate) convicts' behavior: 1) official, provided for by the penal enforcement legislation of the Russian Federation; 2) unofficial, provided for and cultivated by the thieves' ideology. Unofficial norms of behavior differ depending on the regime of correctional colonies. They may impose additional restrictions that apply to all categories (strata) of convicts, regardless of their unofficial status.

Convicts in the correctional facility face a dilemma, whether to follow informal or formal norms of behavior. In the first case they take risks of being punished for regime violation and in the second - their interpersonal relationships in the community are sharpen, thus leading to deterioration of their actual position in the community.

Unofficial norms of behavior prescribe convicts: a) to negatively relate to activities of the correctional facility administration; b) to behave cautiously and deliberately when forced to communicate with representatives of the institution's administration, in exceptional cases, try to gain confidence in order to improve their actual situation; c) not to write complaints, statements to higher judicial authorities with requests for resentence, they do not seek to be released on parole; d) to comply (strictly) with all the instructions of thieves' authorities (crime bosses); e) to be able to stand up for themselves and friends, even if it costs their lives; f) under no circumstances to give anyone any information about the community of convicts; g) to adhere to the following principle: in relationships with others to be careful, keep promises, stick to word, avoid close personal contact with the "hurt", not to delve into other people's conversations, and not to spread rumors; h) to support persons held in punishment cells and celltype wards, meet them after the completion of disciplinary punishment; and) not to participate in crime investigation.

It should be said that the nature of the unofficial norms of behavior prescribed to a certain convict depends on that stratum [23], to which he belongs. The indicated dependence makes it possible to forecast motives, initiators, perpetrators, and behavior of specific persons during and after crime commission. The above, to a certain extent, will be characterized by the following brief plot. In the Correctional Facility No.14 of the Federal Penitentiary System of Russia in the Irkutsk Oblast, the convict R.I.V., who occupies an informal leading position among those serving imprisonment, had suspicions about the involvement of the convicts K.I.V. and V.A.S. in giving confessions in one of the criminal cases, which is a violation of unofficial norms of behavior. He informed K.I.I. and O.S.M. about his suspicions and gave the instruction to teach these persons a lesson. As a result, a group consisting of R.I.V., K.I.I. and O.S.M., by attacking and stabbing with various instruments of crime, killed K.I.V. and V.A.S. (Archive of the Irkutsk Regional Court of the Irkutsk 
Oblast for 2016 Criminal case No. 2-31/2016 of August 1, 2016).

Specifics of personality traits of a subject of the crime and witnesses. The conditions of isolation from society consist in the forced placement of a person in a closed social environment, including a total two-way regulation of behavior (official and unofficial norms of behavior), limiting satisfaction of habitual needs. In case of prolonged stay in places of deprivation of liberty (according to official statistics, 148,000 convicts served sentences from 5 to 10 years) people acquire a set of specific habits. At the same time, existing and acquired personality traits intertwine into a kind of new unity. Then it plays the role of a kind of core, accumulating new personal properties, mainly directed to survive in special conditions and counteract the correctional facility administration, inquirer, and investigator [20, p. 103], improve experience and skills of illegal activity, while there are conditions and persons to adopt such experience (more than 228,000 people were sentenced to imprisonment for the second, third and more times) [15].

Persons held in places of deprivation of liberty transfer stress in the form of unfounded claims, discontent, anger caused by specific conditions of freedom restriction to persons with the same legal status or officials of the correctional facility. This contributes to emergence of a special psychological predisposition to violence among convicts. Sixty-eight percent of violent crimes in correctional facilities are committed with the help of various piercing and cutting objects.

Prevalence of violence in places of deprivation of liberty is caused by: a) deterioration of the socio-criminological characteristics of personality of the convicted (in 2020, 17,143 convicts were recognized as persistent violators of the established order of punishment); b) long term isolation $(320,000$ people serve imprisonment of more than 3 years, that is more than three fourth of the total number of prisoners serving sentences in correctional facilities); c) aggressive atmosphere of social isolation and stressful order and conditions of serving the sentence.

Suspects more often follow unofficial norms of behavior $[1,21,22]$ and try to resolve conflicts without asking for assistance of the correctional facility administration. They take all possible measures to legendize their behavior, presenting it in the best light, explaining what happened by prison traditions and circumstances.

The subjects of the crimes under consideration, in most cases, are young people (18-29 years old), $67 \%$ of whom have secondary or incomplete secondary education. They are the most impulsive, aggressive, easily provoked. Getting into places of deprivation of liberty, in most cases they seek to assert their authority by force. Without thinking about consequences, they often solve their problems by inflicting bodily harm to their abuser, in $65 \%$ of cases without preparation, with a sudden intention. $72 \%$ of them are regime violators. One fourth has been previously convicted of infliction of intentional harm to life and health, the vast majority have various mental abnormalities [9, pp. 88-90]

In some cases, psyche of convicts subjected to humiliation, bullying, physical influence from other persons serving imprisonment undergoes changes that generate anger, aggression as some mechanisms of self-defense against harassment, causing bodily harm. As a result, they become subjects of the analyzed crimes commission.

Features of the victim's personality traits, specifics of behavior before and after commission of the crime against human life and health. Victims are not eager to inform the administration about what has happened, they often do not ask for medical help (there were cases when this had led to tragic consequences). If they provide any information at first, it is not entirely objective. They often refuse to inform, try to "sort out" the offender themselves, succumb to the influence of the criminal's community and formulate statements that they are not only beneficial to the subject of the illegal act, but they can also testify to their own guilt. Sometimes they explain injuries with other facts that exclude human exposure. Changes in indications can also be as a result of receiving certain material benefits (food, clothing, money, cigarettes, tea, narcotic drugs), monetary compensation.

As the results of the practice study show, victims of the crimes under consideration can be divided into 3 main groups. The first one includes owners of negative behavior (42.3\%). They spread negative information, humiliate, insult, cause physical suffering, and mock other convicts. It may provoke commission of the crime. So, in order to take revenge on the 
convicted P.A.P., who had disseminated information discrediting honor and dignity of P.A.V., the latter, who was in the production unit No. 4 of the Center for labor adaptation of convicts of the Correctional Facility No.7 of the Federal Penitentiary Service of Russia in the Udmurt Republic, he struck the offender on the head with a sledgehammer (Archive of the Zavyalovsky District Court of the Udmurt Republic for 2015 Criminal case No. 1-170/2015 of August $25,2015)$. The second group includes convicts who have proven themselves positively during the period of serving their sentence (35.4\%). They defended themselves and others from offenders' unlawful actions by making demands to stop illegal actions, unlawful use of physical force. The convicts N.E.Yu. and Sh.A.V., after cleaning the territory, were returning to the dormitory of their squad in the Correctional Facility No. 17 of the Federal Penitentiary Service of Russia in the Murmansk Oblast, but along the way they met a convict I.A.M., whom they hardly knew, who insulted them without reason. N.E.Yu. asked him to apologize and talk to them in a polite manner, without insulting statements. However, I.A.M., out of hooligan motives, demonstrating his superiority in relation to N.E.Yu., took a nearby lying stick and struck him several blows on the head, causing serious harm to health (Archive of the Leninsky District Court of the city of Murmansk for 2016 Criminal case No. 1-181/2016 of July 25, 2016). The third group consists of convicts with neutral behavior (22.3\%), that is, neither contributing to nor hindering criminal actions. Reasons for this behavior are very different, they are often associated with negative personality traits (cowardice, indecision, habit of pleasing a strong personality, being humiliated).

Thus, there is reason to believe that injured convicts, being in places of deprivation of liberty, are far from ideal in moral terms, as a rule, belong to an unstable community of persons most prone to destructive forms of behavior in the correctional facility, which significantly increases the level of their victimization. The indicated personal qualities also affect their behavior during crime investigation.

\section{Conclusion}

Having studied grounds of criminalistic classification of crimes developed by the predecessors, the authors, studying investigative practice, came to the following conclusion. With regard to crimes against human life and health committed by convicts serving sentences in places of deprivation of liberty, in addition to the universal basis (criminal law object), there are two additional groups - general and private. The general grounds include: 1) a territory, situation, CF community; 2) prevalence of informal norms of behavior in places of deprivation of liberty, which most convicts adhere to. This allows us to state that crimes in places of deprivation of liberty are committed within strictly limited areas, guarded 24 hours a day by individuals and technical means. The correctional facility administration uses audiovisual, electronic and other technical means of supervision and control to obtain information about convicts' behavior. Ideally, neither persons serving sentences can leave protected areas, nor outsiders can enter the territory. In other words, intentional harm to life and health can only be committed by people who are within the protected area. The search for both the criminal and the victim are carried out within the specified limits. At the same time, it is greatly simplified if we keep in mind the use of information technologies (stationary and portable video recorders) and electronic means of controlling the situation and convicts' behavior. As a rule, these crimes are committed among those serving a sentence of imprisonment in the presence of other convicts. In other words, illegal acts occur in the conditions of evidence, when the episode is observed by several people. However, despite the presence of eyewitnesses, suspects and victims, it is difficult to solve and investigate a crime due to prevailing unofficial norms of behavior in places of detention, which most convicts adhere to. They prohibit convicts to take part in the investigation.

The private grounds for classifying crimes against human life and health committed by convicts serving sentences in places of deprivation of liberty are the following: 1) specifics of personality traits of the subject of the crime and witnesses; 2) characteristics of personality traits of the victim, specifics of behavior before and after the commission of the crime causing intentional harm to life and health. Practice shows that investigation of the crimes committed by persons with criminal experience and skills to behave quirkily, deftly, and brazenly at the investigation, complicating activities of inquirers and investigators and thereby the process of cognition, requires the subject of the investigation to be mentally tense 
and creative, use not only criminal procedural actions, but also tactical techniques, technical and informational means. Investigation is also complicated by the specifics of personal characteristics of victims, who often take contradictory positions and change testimony, up to self-incrimination.
Therefore, investigation of such crimes should be based on a complex of various means, not only those provided for by the current criminal procedure legislation of the Russian Federation. These include operationalsearch, regime and other forces, means and methods.

\section{REFERENCES}

1. Akchurin A.V. Lichnost' penitentsiarnogo prestupnika: kriminalisticheskii aspekt: monografiya [Personality of a penitentiary criminal: criminalistic aspect: monograph]. Moscow : Yurlitinform, 2019. 224 p.

2. Belkin A.R. Kriminalisticheskie klassifikatsii [Criminalistic classifications]. Moscow, 2000. 95 p.

3. Belkin R.S., Vinberg A.I. Istoriya sovetskoi kriminalistiki: Formirovanie chastnykh kriminalisticheskikh teorii (1940-e-1950-e gg.): uchebnoe posobie [History of Soviet criminology: formation of private forensic theories (1940th1950th): textbook]. Moscow: Akademiya MVD SSSR, 1983. 78 p.

4. Belkin R.S. Soviet criminalistics course. In: Kriminalisticheskie sredstva, priemy i rekomendatsii: uchebnik [Forensic tools, techniques and recommendations: textbook]. Moscow: Akademiya MVD SSSR, 1979. 407 p.

5. Gerasimov I.F. Nekotorye problemy raskrytiya prestuplenii [Some problems of crime detection]. Ed. by Drapkin L.Ya. Sverdlovsk: Srednee Ural'skoe knizhnoe izdatel'stvo, 1975. 183 p.

6. Golovin A.Yu. Basic criminalistic classifications of crimes. Izvestiya Tul'skogo gosudarstvennogo universiteta. Ekonomicheskie $i$ yuridicheskie nauki=News of the Tula State University. Economic and Legal Sciences, 2013, no 2 (2), pp. 31-40. (In Russ.).

7. Golovin A.Yu. Kriminalisticheskaya sistematika: monografiya [Criminalistic systematics: monograph]. Ed. by Yablokov N.P. Moscow: LeksEst, 2002. 335 p.

8. Davydova N.N. Kriminalisticheskie klassifikatsii prestuplenii i metodik ikh rassledovaniya: teoreticheskie problemy: dissertatsiya na soiskanie uchenoi stepeni kandidata yuridicheskikh nauk [Criminalistic classifications of crimes and methods of their investigation: theoretical problems: Candidate of Sciences (Law) dissertation]. Saratov, 2009. 229 p.

9. Dechkin O.M. Data on the personality characteristics of convicts committed the grievous bodily injury in a correctional facility. Penitentsiarnaya nauka=Penitentiary Science, 2020, vol. 14, no. 1, pp. 86-93. (In Russ.).

10. Kadnikov N.G. Klassifikatsiya prestuplenii po ugolovnomu pravu: monografiya [Classification of crimes in criminal law: monograph]. Moscow: Yuridicheskii institut MVD RF, 2000. 188 p.

11. Kolesnichenko A.N. Nauchnye i pravovye osnovy rassledovaniya otdel'nykh vidov: avtoreferat dissertatsii na soiskanie uchenoi stepeni doktora yuridicheskikh nauk [Scientific and legal bases of investigation of certain types: Doctor of Sciences (Law) dissertation abstract]. Kharkov, 1967. 28 p.

12. Kriminalistika: uchebnik dlya slushatelei pravovykh vuzov [Criminalistics: textbook for law students]. Ed. by A.Ya. Vyshinskii. Moscow: Sovetskoe zakonodatel'stvo, 1936. 126 p.

13. Nikolaichenko V.V. Penitentsiarnye i postpenitentsiarnye prestupleniya: dissertatsiya na soiskanie uchenoi stepeni doktora yuridicheskikh nauk [Penitentiary and post-penitentiary crimes: Doctor of Sciences (Law) dissertation]. Saratov, 2006. 453 p.

14. Obraztsov V.A. Kriminalisticheskaya klassifikatsiya prestuplenii [Criminalistic classification of crimes]. Krasnoyarsk: izdatel'stvo Krasnoyarskogo universiteta, 1988. 176 p.

15. Osnovnye pokazateli deyatel'nosti ugolovno-ispolnitel'noi sistemy Rossiiskoi Federatsii (yanvar'-dekabr' 2020 g.): informatsionno-analiticheskii sbornik [Key performance indicators of the penal enforcement system of the Russian Federation (January-December, 2020): information and analytical collection]. Tver: NIIIT FSIN Rossii, 2021. 418 p.

16. Podol'nyi N.A. Criminalistic classification of crimes as a means of optimizing the investigation. Biblioteka kriminalista=Criminologist's Library, 2014, no. 2 (13), pp. 201-214. (In Russ.).

17. Ruzavin G.I. Metodologiya nauchnogo poznaniya: uchebnoe posobie dlya vuzov [Methodology of scientific cognition: textbook for universities]. Moscow: YuNITI-DANA, 2012. 288 p.

18. Shurukhnov N.G., Meretskii N.E. Types of forensic techniques: their system, interrelation, role in scientific research and investigation of crimes. In: Aktual'nye problemy organizatsii pravookhranitel'noi i pravozashchitnoi deyatel'nosti: materialy Vserossiiskoi nauchno-prakticheskoi konferentsii (g. Tula, 25 yanvarya 2020 g.) [Actual problems of the organization of law enforcement and human rights activities: materials of the All-Russian scientific and practice conference (Tula, January 25, 2020)]. Tula: Tul'skii institut (filial) VGUYu (RPA Minyusta Rossii), 2020. Pp. 205-219. (In Russ.).

19. Shurukhnov N.G. Classification of forensic techniques of crime investigation, its theoretical and practical value. Vestnik Tomskogo gosudarstvennogo universiteta=Tomsk State University Journal, 2020, no. 450, pp. 252-256. (In Russ.).

20. Shurukhnov N.G., Akchurin A.V. Who is a penitentiary offender: a brief description of personality features, their sources, the role in the investigation. Sibirskie ugolovno-protsessual'nye i kriminalisticheskie chteniya=Siberian Criminal Process and Criminalistic Readings, 2021, no. 2 (32), pp. 100-110. (In Russ.).

21. Shurukhnov N.G. Penitentiary criminal personality. Sotsiologicheskie issledovaniya=Sociological Studies, 1993, no. 8, pp. 74-83. (In Russ.).

22. Shurukhnov N.G., Knyaz'kov A.S., Akchurin A.V. The personality of a penitentiary criminal: the concept and criminalistic significance of its properties. Vestnik Tomskogo gosudarstvennogo universiteta. Pravo=Tomsk State University Journal of Law, 2021, no. 39, pp. 109-125. (In Russ.).

23. Shurukhnov N.G. Informal differentiation in correctional labor institutions. Sotsiologicheskie issledovaniya=Sociological Studies, 1992, no. 7, pp. 73-83. (In Russ.).

24. Shurukhnov N.G., Pudovikov A.S., Meretskii N.E. Systematization of forensic techniques: their essence, content, interrelation, official role in scientific research and investigation of crimes. In: Belgorodskie kriminalisticheskie chteniya: 
sbornik nauchnykh trudov [Belgorod forensic readings: collection of scientific papers]. Issue 6. Belgorod: Belgorodskii yuridicheskii institut MVD Rossii imeni I. D. Putilina, - 2020. Pp. 177-190. (In Russ.).

25. Yakimov I.N. Kriminalistika. Rukovodstvo po ugolovnoi tekhnike i taktike [Criminalistics. Manual of criminal technique and tactics]. Moscow: LeksEst, 2003. 496 p.

\section{INFORMATION ABOUT THE AUTHORS}

NIKOLAI G. SHURUKHNOV - Doctor of Sciences (Law), Professor, Leading Researcher of the Group for Training of Scientific-Pedagogical and Scientific Personnel of the Office of the Academic Secretary of Post Graduate Military Course, Doctoral Studies at the Research Institute of the Federal Penitentiary Service of Russia, Moscow, Russian Federation, ORCID: https://orcid.org/0000-0003-1132-760X, e-mail: matros49@mail.ru

OLEG M. DECHKIN - Lecturer of the Department of Criminal Procedure, Criminalistics and Investigation of the Law Faculty of the Vologda Institute of Law and Economics of the Federal Penitentiary Service of Russia, Vologda, Russian Federation, ORCID: https://orcid.org/0000-0002-4956-8655, e-mail: olegd4105@mail.ru

Received October 12, 2021 